\title{
Morphometric and productive characteristics of sorghum genotypes for forage production in the Brazilian semi-arid
}

\author{
Características morfométricas e produtivas de genótipos de sorgo para produção de \\ forragem no semiárido brasileiro
}

MACÊDO, Alberto Jefferson da Silva ${ }^{1 *}$; RAMOS, João Paulo de Farias ${ }^{2}$; SANTOS, Edson Mauro $^{3}$; SOUSA, Wandrick Hauss de ${ }^{2}$; OLIVEIRA, Flávio Gomes de ${ }^{4}$; SOUZA, José Thyago Aires ${ }^{5}$; ORESCA, Denizard ${ }^{6}$

\footnotetext{
${ }^{1}$ Universidade Federal de Viçosa, Programa de Pós-graduação em Zootecnia, Viçosa, Minas Gerais, Brasil.

${ }^{2}$ Empresa Estadual de Pesquisa Agropecuária da Paraíba, João Pessoa, Paraíba, Brasil.

${ }^{3}$ Universidade Federal da Paraíba, Departamento de Zootecnia, Areia, Paraíba, Brasil.

${ }^{4}$ Universidade Federal da Paraíba, Programa de Pós-Graduação em Zootecnia, Areia, Paraíba, Brasil.

${ }^{5}$ Universidade Federal da Paraíba, Programa de Pós-Graduação em Agronomia, Areia, Paraíba, Brasil.

${ }^{6}$ Universidade Federal Rural de Pernambuco, Programa de Pós-Graduação em Fitotecnia, Recife, Pernambuco, Brasil

*Endereço para correspondência: macedoajs@gmail.com
}

\section{SUMMARY}

This study agronomically evaluated 14 sorghum genotypes in the Brazilian semi-arid region. A randomized complete block design, with the treatments represented by sorghum genotypes and three replicates, was used. The dry matter (DM), plant height $(\mathrm{PH})$, number of live leaves, fresh matter production (FMP), dry matter production (DMP), leaf blade (LB), stem, panicle (PAN), dead material, water accumulation (WA), efficiency of rainwater use (ERU) and carrying capacity (SC) were measured. There was an effect of genotype among all the variables. The genotype with the highest percentage of DM was BRS 655 $(26.42 \%)$. The genotypes BRS 655, BRS 506, B1141340, 13F04 (1141572) and PONTA NEGRA produced the most FMP, with values of 48,517, 48,500, 44,879, 44,788 and 43,549 kg/ha, respectively. Not only did the genotypes BRS 655 , B1141340, 13F04 (1141572), BRS 506 and PONTA NEGRA present the highest DMP, with values of $12,426,10,344,9,778,9,756$ and 9,176 $\mathrm{kg} / \mathrm{ha}$, respectively, but also the highest values for ERU, WA and SC. There was a significant positive correlation between productive variables (FMP with DMP, PH, ERU and WA) and a nonsignificant negative correlation between morphometric variables (FMP with LB and PAN). A hierarchical formation of four groups was observed, with groups I and III composed of the most productive genotypes. BRS 655 can be recommended for cultivation since this genotype has desirable agronomic characteristics.

Keywords: dry matter, genotypic variance, Sorghum bicolor, yield

\section{RESUMO}

Objetivou-se avaliar agronomicamente 14 genótipos de sorgo no semiárido brasileiro. Utilizou-se delineamento experimental em blocos casualizados com os tratamentos representados pelos genótipos de sorgo e três repetições. Foram avaliadas matéria seca (MS), altura da planta (AP), número de folhas vivas, produção de matéria verde (PMV), produção de matéria seca (PMS), lamina foliar (LF), colmo, panícula (PAN), material morto (MM), acúmulo de água (ACA), eficiência do uso da chuva (EUC) e capacidade de suporte (CS). Houve efeito entre todas as variáveis. $\mathrm{O}$ genótipo com maior percentual de MS foi BRS 655 (26,42\%). Houve efeito para PMV, os genótipos com maior produção foram BRS 655 , BRS 506, B1141340, 13F04(1141572) e PONTA NEGRA, com valores de 48.517, 48.500, 44.879, 44.788, $43.549 \mathrm{~kg} / \mathrm{ha}$. Os genótipos que apresentaram maior PMS foram BRS 655, B1141340, 13F04(1141572), BRS 506 e PONTA NEGRA, com valores de 12.426, 10.344, 9.778, $9.756 \mathrm{e}$ $9.176 \mathrm{~kg} / \mathrm{ha}$, respectivamente e também 
apresentaram maiores valores para EUC, ACA e CS. Houve correlação positiva significativa entre variáveis produtivas (PMV com PMS, AP, EUC e ACA) e correlação negativa não significativa (PMV com LF e PAN) com variáveis morfométricas. Houve formação hierárquica de quatro grupos, sendo os grupos I e III compostos pelos genótipos mais produtivos. $\mathrm{O}$ genótipo BRS 655 pode ser recomendado para o cultivo, pois possui características agronômicas desejáveis.

Palavras-chave: matéria seca, variância genotípica, Sorghum bicolor, produtividade

\section{INTRODUCTION}

Arid and semi-arid regions experience long periods of drought, affecting the availability of food for livestock and causing low production performance, economic loss and possibly even death of the animals (SALEM, 2010).

The northeast region of Brazil presents a mostly semi-arid climate, characterized by low rainfall, high solar radiation rates and scarce water sources. The predominant native vegetation is the Caatinga, which generally presents low support capacity (SC) and low biomass production when compared to cultivated pastures (OLIVEIRA et al., 2015). In this context, the use of forage conservation in the form of pasture, green forage, hay or silage becomes an indispensable practice in periods of food shortage (MOREIRA et al., 2007).

Sorghum (Sorghum bicolor L.) is economically important in agricultural production systems, as it has favorable cultivation characteristics. It is a crop with high potential for use in arid and semi-arid regions, displaying a high efficiency of rainwater use (ERU), high biomass production, and a high tolerance to salinity and soils with hydric deficiency. Moreover, it can be cultivated for various purposes, i.e., grains and forage (PATERSON, 2008; GETACHEW et al., 2016).

Studies show that agronomic trials allow distinguishing genetic materials with potential for genetic selection and breeding of the crop, which can increase production and productivity (CYSNE \& PITOMBEIRA, 2012; ELIAS et al., 2016). Identifying promising sorghum genotypes requires research focused on the crop's morphological and structural adaptive characteristics that correlate positively with its forage mass production (CASTRO et al., 2015). In this way, sorghum genetic materials can be generated that are more adapted to the environmental conditions of the cultivation region.

Considering animal feeding in semi-arid regions of the Brazilian northeast, it is necessary to evaluate any new genotypes developed so that rural producers can be provided with the genetic material and technical information for the use of sorghum in the production system (CYSNE \& PITOMBEIRA, 2012; CASTRO et al., 2015; MARTINS, 2015; SHER et al., 2016).

Thus, it was hypothesized that when evaluating the morphometric and productive characteristics of sorghum genotypes in semi-arid conditions, it would be possible to identify at least one or more genotypes with the potential to be indicated for cultivation.

The objective of this study was to quantify forage yield, efficiency of rainwater use, agronomic characteristics and support capacity of 14 sorghum genotypes, for forage production in the Brazilian semi-arid region.

\section{MATERIAL AND METHODS}

The experiment was carried out from May to July 2016 at the Benjamin 
Maranhão Experimental Station, belonging to the State Company of Agricultural Research of Paraiba SA (EMEPA), located in the Meso-region of the Paraiba Agreste, Microregion of the Curimataú Oriental, municipality of Tacima, Paraiba, Brazil. The location has geographic coordinates of $6^{\circ} 29^{\prime} 16^{\prime \prime} \mathrm{E}$ and $35^{\circ} 38^{\prime} 13^{\prime \prime} \mathrm{W}$, with an altitude of $168 \mathrm{~m}$.

Table 1 describes the chemical attributes of the experimental area in the 0 to $20 \mathrm{~cm}$ deep layer. The sowing of sorghum genotypes was performed manually on 5
May 2016, in $8.4 \mathrm{~m}^{2}(4.2 \times 2.0 \mathrm{~m})$ plots. Twenty days after planting, the thinning was done, keeping 12 plants per meter. Fertilization was carried out based on the soil chemical attributes of the experimental area, using $30 \mathrm{~kg} / \mathrm{ha}$ of potassium in the form of potassium chloride, phosphorus fertilization of 60 $\mathrm{kg} / \mathrm{ha}$ of $\mathrm{P}_{2} \mathrm{O}_{5}$, and an application of 50 $\mathrm{kg} / \mathrm{ha}$ of nitrogen in the form of ammonium sulfate, at 30 days after sowing.

Table 1. Chemical attributes of soil belonging to experimental area

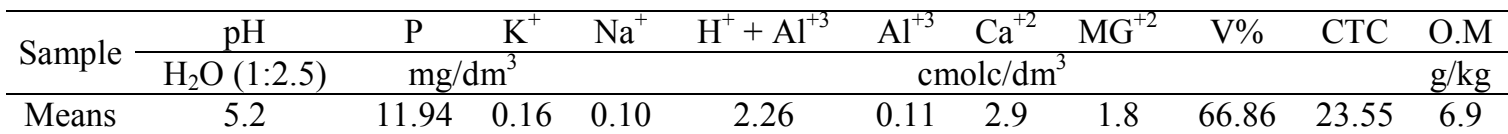

$\mathrm{P}, \mathrm{K}, \mathrm{Na}=$ mehlich extractor $1 ; \mathrm{H}+\mathrm{Al}=$ extractor calcium acetate $0.5 \mathrm{M}, \mathrm{pH} 7.0 ; \mathrm{H}+\mathrm{Al}=$ extractor calcium acetate $0.5 \mathrm{M}, \mathrm{pH} 7.0 ; \mathrm{Al}, \mathrm{Ca}, \mathrm{Mg}=1 \mathrm{M} \mathrm{KCl}$ extractor; O.M. = organic matter - walkley-black; V\%: base saturation.

We evaluated 14 sorghum genotypes (SF15, FEPAGRO17, FEPAGRO18, PONTA NEGRA, BRS 506, 13F02, 13F039, 13F04, 13F05, A1141128A, P47216, B1141562, C947072 and BRS 655), developed by the Brazilian Agricultural Research Corporation (EMBRAPA).

The experimental design was in randomized blocks, with three replications. Each plot was composed of six rows with an inter-row spacing of 0.70 $\mathrm{m}$, useful area of the each plot of three central rows with a total of $8.4 \mathrm{~m}^{2}$. Harvesting was performed when the grains reached a milky/pasty stage.

The duration of the cycle was 80 days. Figure 1 shows the rainfall data distributed by 5-day intervals. The total accumulation of rainfall during the sorghum cycle in the present study, from the planting day to harvest, was 114.7 $\mathrm{mm}$.
The evaluated characteristics were dry matter (DM, \%), organic matter (OM, \%), plant height $(\mathrm{PH}, \mathrm{m})$, quantifiable number of live leaves (NLL), fresh matter production (FMP, kg/ha), dry matter production (DMP, $\mathrm{kg} / \mathrm{ha}$ ), water accumulation (WA, $\mathrm{kg} / \mathrm{ha}$ ) and efficiency of rainwater use (ERU, $\mathrm{kg} \mathrm{DM} / \mathrm{mm}$ ).

The material was manually harvested from each plot using a machete, with cutting at ground level. As mentioned above, the material was cut when the grains were at the milky/pasty stage. After cutting, the material was separated and expressed as a percentage of the DM, panicle (PAN), leaf blade (LB), stems (STE) and dead material (DEM), quantifying the weight in $\mathrm{kg}$ of each component separately. A subsample of each fraction was dried in an oven with forced ventilation at $65^{\circ} \mathrm{C}$ until reaching a constant dry mass weight, to estimate the DM content. From these data, the percentage of each of the plant 
components was estimated, based on the DM. The fresh matter production per hectare was obtained by the product between fresh mass obtained by linear meter, harvested converted to the total of linear meters/hectare. The dry matter production was estimated by multiplying the fresh matter production by the DM content, being converted to DMP/ha.

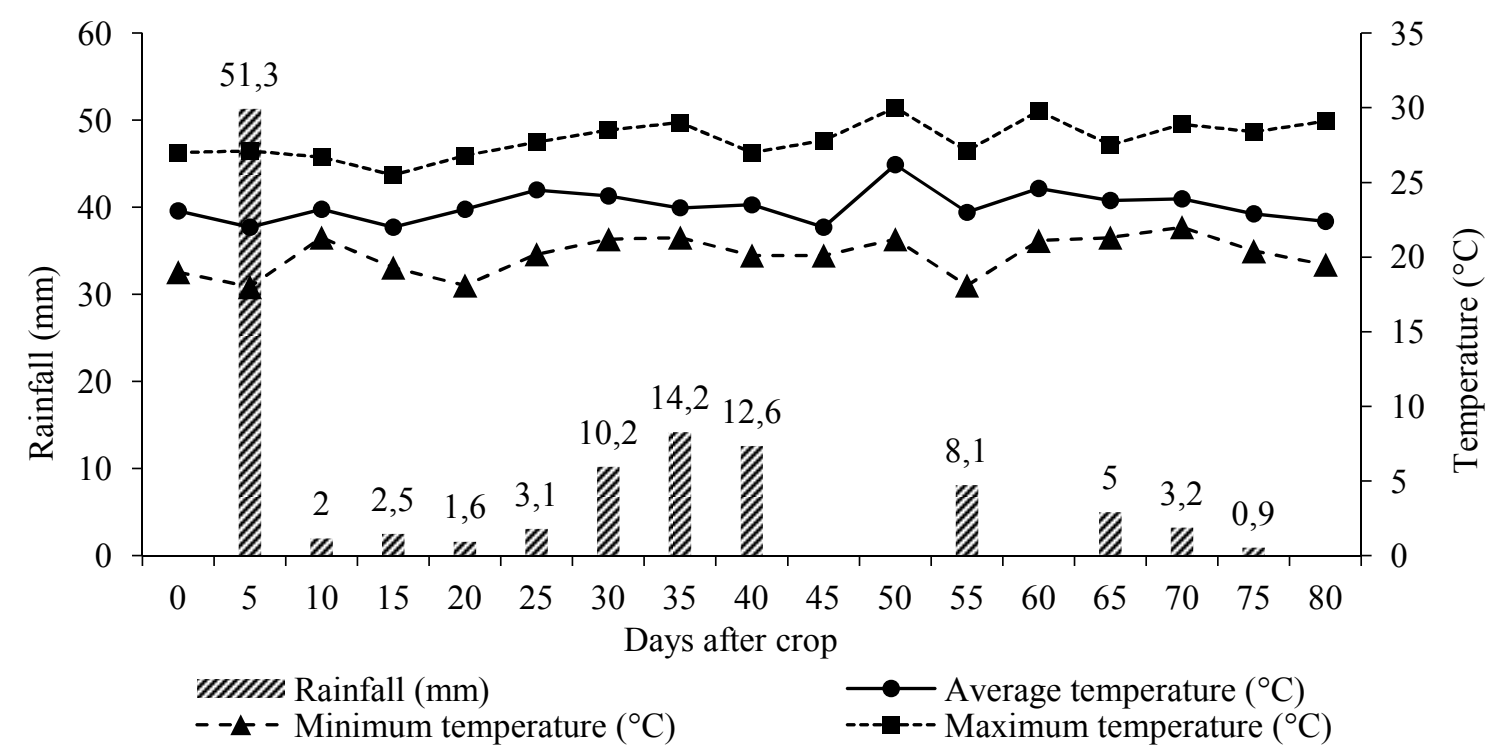

Figure 1. Precipitation, average, minimum and maximum temperatures, every five days during the experimental period, Source: Elaborated by the authors

The efficiency of rainwater use for dry matter production, given in $\mathrm{kg} \mathrm{DM} / \mathrm{mm}$, was estimated by dividing the dry matter production by the amount of rain accumulated during the cycle $(114 \mathrm{~mm})$. The water accumulation ( $\mathrm{kg} / \mathrm{ha}$ ) by the plants was estimated by the difference between fresh matter production and dry matter production. The support capacity was estimated by mathematical calculations, considering animals confined for 60 days, with a mean live weight of $24 \mathrm{~kg}$, consuming $4 \%$ of the live weight of DM, with a 55:45 forageto-concentrate ratio.

Data were analyzed for variance, to verify the existence of variability of the agronomic characteristics among the 14 sorghum genotypes. Pearson's correlation analysis was performed to identify associative effects among all variables studied. The objective was to select discriminatory variables for multivariate cluster analysis.

Multivariate analyzes were performed to form homogeneous groups among the 14 sorghum genotypes by the Ward method (minimum variance). Accordingly, the mean Euclidean distance was adopted as a measure of dissimilarity with the standardized data, and variables with a relatively higher degree of independence, and with biological importance for animal nutrition and forage production, were used.

The results were submitted to analysis of variance and the Scott-Knott test at 5\% probability level, using the System of Statistical and Genetic Analysis (SAEG, 2007). 


\section{RESULTS AND DISCUSSION}

According to Table 2, fresh matter production was positively correlated with dry matter production (significance at 5\% and $1 \%, *, * *$, respectively $)(\mathrm{r}=$ $\left.0.965^{* *}\right)$, plant height $(\mathrm{r}=0.502 * *)$ and efficiency of rainwater use $(\mathrm{r}=0.962 * *)$. The water accumulation $\left(\mathrm{r}=0.997^{* *}\right)$ was positively correlated with stem $(\mathrm{r}=$ $0.132)$, dead material $(r=0.120)$ and quantifiable number of live leaves $(r=$ 0.210 ), and negatively correlated with leaf blade $(\mathrm{r}=-0.975)$ and panicle $(\mathrm{r}=$ 0.247).

The selection of genetic material for characteristics that correlate to the detriment of the selection made from isolated variables. Elucidating how associative effects among these variables interact with each other, is essential to determine the choice of genetic materials that have desirable attributes for forage production.

Cunha \& Lima (2010) demonstrated that the higher the plant height, the higher its yield in dry matter production; this effect can be reversed when plant height and the number of tillers are reduced. The higher yield of dry matter as plant height increases may be associated with the sensitivity of the sorghum plant in relation to the photoperiod, providing greater stretching between nodes. With the greater development of stems, there is the possibility of increasing the concentration of the fibrous fractions, causing a decrease in forage quality.

Table 2. Pearson correlation coefficients among the agronomic characteristics of 14 sorghum genotypes

\begin{tabular}{lccccccccc}
\hline Item & FMP & DMP & LB & STE & PAN & DM & PH & NLL & ERU \\
\hline DMP & $0.965^{* *}$ & - & - & - & - & - & - & - & - \\
LB (\%) & -0.975 & 0.005 & - & - & - & - & - & - & - \\
STE (\%) & 0.132 & 0.087 & -0.542 & - & - & - & - & - & - \\
PAN (\%) & -0.247 & -0.181 & 0.034 & -0.447 & - & - & - & - & - \\
DM (\%) & 0.120 & 0.059 & -0.004 & -0.474 & -0.416 & - & - & - & - \\
PH (m) & $0.502^{* *}$ & $0.505^{* *}$ & -0.077 & 0.010 & 0.167 & 0.196 & - & - & - \\
NLL & 0.210 & 0.081 & -0.573 & $0.318^{*}$ & -0.107 & 0.073 & 0.175 & - & - \\
ERU & $0.962^{* *}$ & $0.999^{* *}$ & 0.005 & 0.087 & -0.181 & 0.059 & $0.505^{* *}$ & 0.081 & - \\
WA & $0.997^{* *}$ & $0.942^{* *}$ & -0.098 & 0.143 & -0.263 & 0.136 & $0.494^{* *}$ & 0.244 & $0.942^{* *}$ \\
\hline
\end{tabular}

$\mathrm{FMP}=$ fresh matter production $(\mathrm{kg} / \mathrm{ha}) ; \mathrm{DMP}=$ dry matter production $(\mathrm{kg} / \mathrm{ha}) ; \mathrm{LB}(\%)=$ percentage of leaf blade; STE $(\%)=$ percentage of stem; PAN $(\%)=$ panicle percentage; DM $(\%)=$ percentage of dead matter; PH $(\mathrm{m})=$ plant height; $\mathrm{NLL}=$ number of live leaves; ERU = efficiency of rainwater use $(\mathrm{kg}$ $\mathrm{DM} / \mathrm{mm}) ; \mathrm{WA}=$ water accumulation $(\mathrm{kg} / \mathrm{ha})$.

Probability of significance * $(\mathrm{P}<0.05) ; * *(\mathrm{P}<0.01)$.

Perazzo et al. (2014) evaluated the agronomic characteristics of 32 sorghum cultivars in the Brazilian semi-arid region and found that dry matter production correlated with fresh matter production $(\mathrm{r}$ $\left.=0.8754^{* *}\right)$ and plant height $(\mathrm{r}=$ $\left.0.61210^{* *}\right)$. This effect influences the choice of genetic material with desirable characteristics intended for silage production.

The positive correlation of the fresh matter production with the efficiency of rainwater use and water accumulation is a potential way to identify promising 
genetic materials because the efficiency of rainwater use is associated with the plant's ability to use water to convert to dry matter, and the water accumulation is related to the water concentration present in the vegetable. These characteristics are essential for crops destined to be cultivated in environments with arid and semi-arid climates, low rainfall indices and poorly distributed rainfall, as in the case of semi-arid Brazilian northeast.

For the proportions of plant components assessed in the present study, no significant correlation was found between leaf blade, panicle and dead material with the other variables analyzed. For stem, there was a low positive correlation with quantifiable number of live leaves $(r=$ 0.318). Panicle displayed a low positive correlation and several negative correlations with the other variables. For dead material, there were several low correlations, presenting little significance of this variable with the others. This outcome was probably because the components are not associated with the plant population per unit area, although the plant components have a close relationship with height (VAN BUREN et al., 2015).

Considering the common occurrence of multiple alleles, there should not necessarily be a correlation of these components with the plants height, because the genes that influence the expression of these characteristics are diverse, displaying intralocus or interlocus interactions, causing the allelic interactions to be less prominent (MACE et al., 2009). Probably, due to the origin of the genetic material that was used to elaborate these genotypes (forage, saccharin, graniferous and broom), the hybridization of different genetic materials to create new genotypes may influence the predominance of some characteristics, since different interactions may occur between some genes, when crossed (PATERSON, 2008).

To evaluate the discriminatory agronomic characteristics, we used fresh matter production, dry matter production, leaf blade, stem, panicle, dead material, plant height, number of live leaves, efficiency of rainwater use and water accumulation. The results were expressed in the dissimilarity dendrogram (Figure 2). According to the dendrogram, the hierarchical formation of four groups was observed, considering $20 \%$ of dissimilarity. The formation of the groups considered a Euclidean distance of 3.75. The dissimilarity dendrogram (Figure 2) demonstrated the existence of variability within each group, indicating that some cultivars may stand out from the others in relation to the agronomic characteristics.

Group I was composed of the genotypes SF 15 and BRS 655. Group II was composed of the genotypes P 47216, A1141128A, FEPAGRO 17, 13 F039, 13 F05, 13 F02 and C947072. Group III was formed by cultivars PONTA NEGRA, BRS 506 and 13 F04. Group IV comprised the cultivar FEPAGRO 18. There were differences $(\mathrm{P}<0.05)$ between the sorghum genotypes evaluated (Table $3)$. The percentage of dry matter varied from 21.05 to $24.74 \%$ for the genotypes PONTA NEGRA and SF15, respectively, presenting a general average of $23.03 \%$ DM. Quantification of the dry matter content of a particular food is essential since it is the basis on which diets to be offered to the animals are calculated. Such information informs the concentration of the nutrients and enables identifying the optimum level to meet the nutritional requirements of animals, for maintenance, weight gain, gestation and milk production, for example (HARPER et al., 2017). 


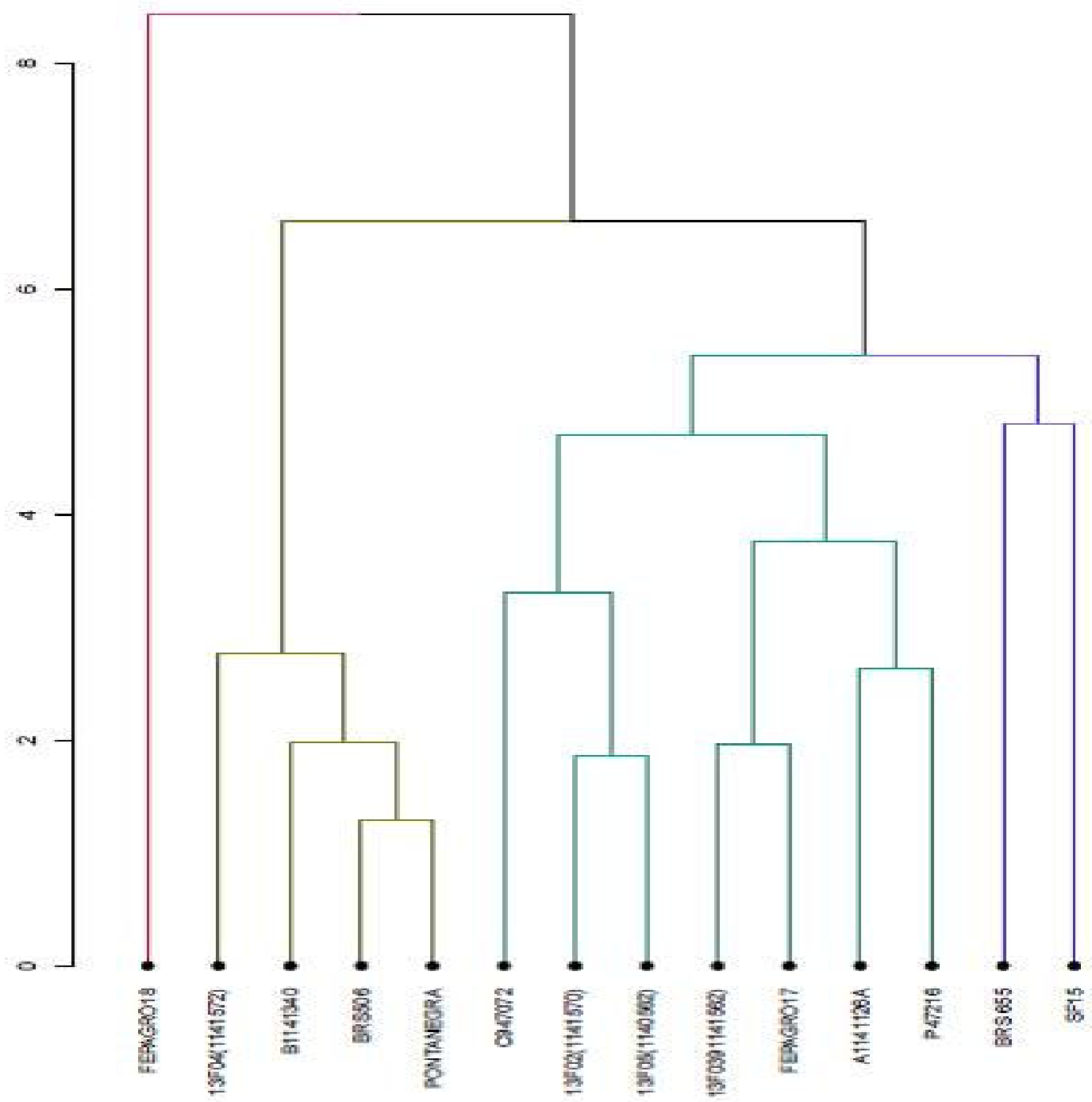

Figure 2. Dendogram of dissimilarity of the agronomic characteristics of 14 sorghum genotypes

The dry matter content tends to increase due to the maturity of the crop, as well as to the suitability of the genetic material. Usually, medium-sized and doublepurpose cultivars tend to present an early cycle and a comparatively higher dry matter content, mainly due to the relatively higher panicle participation (PERAZZO et al., 2013).

Perazzo et al. (2013) evaluated the agronomic characteristics and efficiency of rainwater use of five sorghum cultivars (PONTA NEGRA, SF 15, IPA 1011, IPA 2502 and IPA 46742) in the Brazilian semi-arid region. The dry matter of the evaluated cultivars varied from 23.25 to $33.34 \%$, for IPA 1011 and PONTA NEGRA, respectively $(\mathrm{P}<0.05)$. The authors attributed this result to the genetic material from which the cultivars were used, since each variety of sorghum has a certain aptitude, regarding grain production and fodder. However, when cultivars are crossed with each other, the created hybrids will express characteristics of both parties that gave rise to them and, especially, those features with a relatively greater degree of dominance. 
The fresh matter production varied among the evaluated genotypes $(\mathrm{P}<0.05)$, ranging from 12,005 to $48,517 \mathrm{~kg} / \mathrm{ha}$, for the FEPAGRO 18 and BRS 655 genotypes, respectively (Table 3 ). The fresh matter production represents one of the several evaluation parameters in crop genetic improvement programs, since knowing the fresh matter production potential of a given culture influences the feeding of ruminant animals, directly, mainly as a source of bulking (ELIAS et al., 2016).

Table 3. Mean values of dry matter (DM), fresh matter production (FMP), dry matter production (DMP), efficiency of rainwater use (ERU), water accumulation (WA) and support capacity (SC) for sheep of 14 genotypes of Sorghum in the semiarid

\begin{tabular}{lcccccc}
\hline Genotype & DM $(\%)$ & $\begin{array}{c}\text { FMP } \\
(\mathrm{kg} / \mathrm{ha})\end{array}$ & $\begin{array}{c}\text { DMP } \\
(\mathrm{kg} / \mathrm{ha})\end{array}$ & $\begin{array}{c}\text { ERU } \\
(\mathrm{kg} \mathrm{DM} / \mathrm{mm})\end{array}$ & $\begin{array}{c}\text { WA } \\
(\mathrm{kg} / \mathrm{ha})\end{array}$ & $\begin{array}{c}\text { SC } \\
(\text { sheep/ha })\end{array}$ \\
\hline SF 15 & $24.74^{\mathrm{ab}}$ & $33,273^{\mathrm{ab}}$ & $8,193^{\mathrm{ab}}$ & $71.87^{\mathrm{ab}}$ & $25,083.28^{\mathrm{a}}$ & $218^{\mathrm{a}}$ \\
FEPAGRO 17 & $22.81^{\mathrm{ab}}$ & $34,428^{\mathrm{ab}}$ & $7,857^{\mathrm{ab}}$ & $68.92^{\mathrm{ab}}$ & $26,570.10^{\mathrm{a}}$ & $209^{\mathrm{ab}}$ \\
FEPAGRO 18 & $23.11^{\mathrm{ab}}$ & $12,005^{\mathrm{b}}$ & $2,900^{\mathrm{b}}$ & $25.44^{\mathrm{b}}$ & $91,04.67^{\mathrm{a}}$ & $77^{\mathrm{b}}$ \\
PONTA NEGRA & $21.05^{\mathrm{b}}$ & $43,549^{\mathrm{a}}$ & $9,176^{\mathrm{a}}$ & $80.49^{\mathrm{a}}$ & $34,372.28^{\mathrm{a}}$ & $244^{\mathrm{a}}$ \\
BRS 506 & $21.69^{\mathrm{b}}$ & $44,879^{\mathrm{a}}$ & $9,756^{\mathrm{a}}$ & $85.58^{\mathrm{a}}$ & $35,122.50^{\mathrm{a}}$ & $260^{\mathrm{a}}$ \\
13F02(1141570) & $21.91^{\mathrm{b}}$ & $34,293^{\mathrm{ab}}$ & $7,520^{\mathrm{ab}}$ & $65.96^{\mathrm{ab}}$ & $26,773.12^{\mathrm{a}}$ & $200^{\mathrm{ab}}$ \\
13F039(1141562) & $23.37^{\mathrm{ab}}$ & $30,929^{\mathrm{ab}}$ & $7,148^{\mathrm{ab}}$ & $62.70^{\mathrm{ab}}$ & $23,781.24^{\mathrm{a}}$ & $190^{\mathrm{ab}}$ \\
13F04(1141572) & $22.07^{\mathrm{b}}$ & $44,788^{\mathrm{a}}$ & $9,778^{\mathrm{a}}$ & $85.77^{\mathrm{a}}$ & $35,000.03^{\mathrm{a}}$ & $260^{\mathrm{a}}$ \\
13F05(1140562) & $22.99^{\mathrm{ab}}$ & $32,571^{\mathrm{ab}}$ & $7,201^{\mathrm{ab}}$ & $63.16^{\mathrm{ab}}$ & $25,359.99^{\mathrm{a}}$ & $192^{\mathrm{ab}}$ \\
A1141128A & $22.23^{\mathrm{b}}$ & $36,647^{\mathrm{a}}$ & $8,531^{\mathrm{ab}}$ & $73.25^{\mathrm{ab}}$ & $29,295.71^{\mathrm{a}}$ & $222^{\mathrm{ab}}$ \\
P47216 & $23.58^{\mathrm{ab}}$ & $31,478^{\mathrm{ab}}$ & $7,800^{\mathrm{ab}}$ & $68.42^{\mathrm{ab}}$ & $23,687.94^{\mathrm{a}}$ & $208^{\mathrm{ab}}$ \\
B1141340 & $21.33^{\mathrm{b}}$ & $48,500^{\mathrm{a}}$ & $10,344^{\mathrm{a}}$ & $90.73^{\mathrm{a}}$ & $38,156.76^{\mathrm{a}}$ & $275^{\mathrm{a}}$ \\
C947072 & $24.61^{\mathrm{ab}}$ & $31,119^{\mathrm{ab}}$ & $7,747^{\mathrm{ab}}$ & $67.96^{\mathrm{ab}}$ & $23,371.46^{\mathrm{a}}$ & $206^{\mathrm{ab}}$ \\
BRS 655 & $26.42^{\mathrm{a}}$ & $48,517^{\mathrm{a}}$ & $12,426^{\mathrm{a}}$ & $109.00^{\mathrm{a}}$ & $36,090.84^{\mathrm{a}}$ & $331^{\mathrm{a}}$ \\
\hline Mean & 23.03 & 36,283 & 8,299 & 72.80 & $27,983.56$ & 279 \\
\hline CV $(\%)$ & 8.45 & 30.05 & 34.13 & 34.13 & 33.34 & 34.46 \\
\hline
\end{tabular}

Means followed by the same letter in the column do not differ by Scott-Knott's test, at 5\% probability;

${ }^{1} \mathrm{CV}=$ coefficient of variation

The cultivation environment directly impacts on the productive response of a crop, so the sorghum culture was influenced by the edaphoclimatic conditions of the cultivation environment. It is believed that a probable cause of the low fresh matter production was the water deficit that the crop underwent during the cultivation period. As Figure 1 shows, more than $58 \%$ of the total rainfall occurred in the first 5 days after sowing, whereas, in the last 20 days before harvesting, only $9.10 \mathrm{~mm}$ of rain fell. Similar results were obtained by Silva et al. (2011), evaluating the agronomic potential of 25 sorghum hybrids for silage production. In that study, the fresh matter production values were $22,529.79$ to $44,629 \mathrm{~kg} / \mathrm{ha}$, during 113 days of cultivation with $466.84 \mathrm{~mm}$ of rainfall.

In comparison to the current results, Cunha \& Lima (2010) verified marked differences in the characteristics $(\mathrm{P}<0.05)$ of 29 genotypes of forage sorghum in the state of Rio Grande do Norte, Brazil. Among the several attributes evaluated, the authors found the fresh matter production average ranged from 45,333 to $68,100 \mathrm{~kg} / \mathrm{ha}$. The same authors demonstrated positive genotypic 
correlations of high magnitude (greater than 0.70) between fresh matter production and dry matter. Santos \& Granjeiro (2013) documented variations in the fresh matter production of sorghum and forage sorghum cultivars grown in Brazilian semi-arid conditions, with values in the order of 13,100 to 33,670 $\mathrm{kg} / \mathrm{ha}$, for the cultivars IPA 1011 and PONTA NEGRA, respectively.

The current work revealed an effect of the genotype $(\mathrm{P}<0.05)$ on dry matter production, which varied from 2,900 to $12,426 \mathrm{~kg} / \mathrm{ha}$, for FEPAGRO 18 and BRS 655 , respectively. These results were probably influenced by the origins and, hence, different features of the genetic materials that were used. The climatic factor was also influential, as during the experimental period, a rainfall of only $114.7 \mathrm{~mm}$ occurred (Figure 1).

Knowing the dry matter production potential of a crop is essential since this variable is positively correlated with the dry matter content and fresh matter production. Also, plant crops with a high dry matter production efficiency tend to reduce production costs, since the cost of the crop varies little and enhanced dry matter yields are desirable to dilute costs and increase crop yields, either for in natura supply, hay or silage production (CUNHA \& LIMA, 2010).

The research results for fresh matter production and dry matter production demonstrate the high efficiency and adaptability of the studied sorghum genotypes to arid and semi-arid climates because, with a cycle of 80 days of cultivation and $114.7 \mathrm{~mm}$ rainfall, it would be difficult to produce the same amount of biomass or higher than in the present study. Figure 1 indicates that more than $58 \%$ of all rainfall was available for the crop in the first 5 days after planting, meaning it had to use adaptive mechanisms to suit the environmental conditions imposed.
Due to climatic variations in several parts of the globe, studying crops that adapt to water scarcity conditions is critical, since the availability of water for irrigation is likely to decrease in the future. The sorghum crop stands out due to its high efficiency in less demanding soil and water quantity when compared to other crops, mainly, maize (GETACHEW et al., 2016).

Sorghum cultivation is known to have adaptive characteristics in relation to being cultivated in arid and semi-arid environments. Like any vegetable, this crop is subjected to biotic and abiotic factors that can delay its development (MAGALHÃES \& DURÃES, 2003).

The data obtained in the present study demonstrate that in low rainfall, sorghum shows high adaptability to difficulties in the cultivation environment. The crop could produce satisfactory amounts of biomass, representing an excellent alternative for years of atypical cultivation when the developments of other cultures can be made unfeasible. Sorghum has an efficient water absorption capacity due to its deep and subsurface roots, as well as being able to adjust its phenological cycle as a function of environmental conditions (SILVA et al., 2011).

For the efficiency of rainwater use and dry matter production (Table 3), genotype FEPAGRO 18 presented a lower efficiency of $25.44 \mathrm{~kg} \mathrm{DM} / \mathrm{mm}$ compared to BRS 655, which showed an efficiency of $109.00 \mathrm{~kg} \mathrm{DM} / \mathrm{m}(\mathrm{P}<0.05)$. From this perspective, the BRS 655 genotype was the most efficient while for water accumulation, there was no effect $(\mathrm{P}<0.05)$ among the evaluated genotypes, with an average value of $27,983.56 \mathrm{~kg} / \mathrm{ha}$. The efficiency of rainwater use and water accumulation data presented here differed from those reported by Perazzo et al. (2013) evaluating the agronomic characteristics and efficiency of rainwater 
use of five sorghum cultivars (PONTA NEGRA, SF 15, IPA 1011, IPA 2502 and IPA 46742). In that work, the efficiency of rainwater use of the evaluated cultivars ranged from 94.23 to $126.67 \mathrm{~kg} \mathrm{DM} / \mathrm{mm}$ for DIPASP SF 15 and IPA 1011, respectively $(\mathrm{P}<0.05)$. Also, the authors did not observe significant differences $(\mathrm{P}>0.05)$ for water accumulation, with mean values of 220.60 to 348.41 $\mathrm{kg} / \mathrm{ha} / \mathrm{mm}$, for IPA 2502 and PONTA NEGRA, respectively.

Elias et al. (2016) examined the efficiency of rainwater use and the agronomic performance of four sorghum cultivars (IPA 2502, BRS 810, BRS 700 and BRS 655) under a no-tillage system in the semi-arid region of Pernambuco. It was verified that the efficiency of rainwater use between cultivars ranged from $27.44 \mathrm{~kg} \mathrm{DM} / \mathrm{mm}$ for cultivar BRS 655 to $82.52 \mathrm{~kg} \mathrm{DM} / \mathrm{mm}$ for IPA 2502 . The fresh matter production varied from 7,100 to $20,770 \mathrm{~kg} / \mathrm{ha}$, for cultivars BRS 655 and IPA 2502, respectively.

Considering that in the arid and semi-arid regions the water deficit is recurrent, genetic enhancement programs should consider these variables, to select and develop new cultivars that have less demand for water and retain a certain amount of water that can be used by animals (water source via food) (MAGALHÃES \& DURÃES，2003; PERAZZO et al., 2013).

For support capacity, there was an effect $(\mathrm{P}<0.05)$ among the evaluated genotypes, ranging from 177 to 311 sheep/ha, for FEPAGRO 18 and BRS 655, respectively. Once again, BRS 655 presented as a superior genetic material compared to the others, for most of the analyzed variables. Although the support capacity was derived from estimates and the unit used does not mean that the sheep will graze the area cultivated with the sorghum, this area of $1 \mathrm{ha}$, according to the estimation, allows to feed a maximum of 331 animals with an average daily intake of $4 \%$ of the live weight and considering a 55:45 forage-to-concentrate ratio, which would be received in a field situation via the feed silage, for example. The support capacity results demonstrate the high efficiency of biomass production by sorghum and that high support capacity, when compared to the other genotypes, is directly related to characteristics, such as an adequate dry matter content and a high dry matter production.

Neves et al. (2015) mentioned several features are desirable to produce a promising sorghum genetic material. Among them, a good nutritional value, high digestibility and starch content, and a balanced stem-to-leaf ratio and relative panicle percentage can be highlighted.

Harper et al. (2017) assessed the effects on milk production and composition in Holstein cows being fed with two alternative sources of forage (oat silage and sorghum silage instead of corn silage). The authors verified that the oat silage did not interfere $(\mathrm{P}>0.05)$ with the milk production and composition characteristics while sorghum silage caused decrease dry matter intake by the animals, but in compensation, increased the milk protein content. Sorghum silage is an alternative in the feeding of animals, in which, the feed must be adjusted to meet the nutritional requirements of the animals because otherwise, there will be a decrease in the productive performance (GETACHEW et al., 2016).

Due to the particular characteristics that the semi-arid region of the Brazilian northeast has, one of the main difficulties faced by the producers is the lack of food to feed the herds, where pastures do not develop, and the alternative would be to use a food source, whether in the in natura form, hay or silage. In the present study, sorghum is presented as an 
alternative food that can be used by farmers to feed the herds.

According to the cultivation conditions, the sorghum genotypes evaluated demonstrated high adaptability to the conditions of the semi-arid environment, with satisfactory production under water stress. The genotype BRS 655 can be recommended for cultivation since it has desirable agronomic characteristics.

\section{REFERENCES}

CASTRO, F.M.R.; BRUZI, A.T.; NUNES, J.A.R.; PARRELLA, R.A.C.; LOMBARDI, G.M.R.; ALBUQUERQUE, C.J.B.; LOPES, M. Agronomic and energetic potential of biomass sorghum genotypes. American Journal of Plant Sciences [online], v.6, p.1862-1873, 2015.

CUNHA, E.E.; LIMA, J.M.P. Characterization of genotypes and estimation of genetic parameters of productive characteristics of forage sorghum. Revista Brasileira de Zootecnia [online], v.39, n.4, p.701-706, 2010.

CYSNE, J.R.; PITOMBEIRA, J.B. Adaptability and stability of sorghum genotypes in different environments in the state of Ceará. Revista Ciência Agronômica [online], v.43, n.2, p.273$278,2012$.

ELIAS, O.F.A.S.; LEITE, M.L.M.V.; AZEVEDO, J.M.; SILVA, J.P.S.S.; NASCIMENTO, G.F.; SIMPLÍCIO, J.B.

Agronomic characteristics of sorghum cultivars under no-tillage system in the semi-arid region of Pernambuco. Revista Ciência Agrícola [online], v.14, n.1, p.29-36, 2016.
GETACHEW, G.; PUTNAM, D.H.; BEN, C.M.; PETERS, E.J. Potential of sorghum as an alternative to cor forage. American Journal of Plant Sciences [online], v.7, p.1106-1121, 2016.

HARPER, M.T.; OH, J.; GIALLONGO, F.; LOPES, J.C.; ROTH, G.W.; HRISTOV, A.N. Using brown midrib 6 dwarf forage sorghum silage and fallgrown oat silage in lactating dairy cow rations. Journal of Dairy Science [online], v.100, n.7, p.5250-5265, 2017.

MACE, S.E.; RAMI, J.F.; BOUCHET, S.; KLEIN, P.E.; KILIAN, A.; WENZL, P.; XIA, L.; HALLORAN, K.; JORDAN, D.R. A consensus genetic map of sorghum that integrates multiple component maps and high-throughput diversity array technology (DArT) markers. BMC Plant Biology [online], v.9, n.13, p.1-14, 2009.

MAGALHÃES, P.C.; DURÃES, F.O.M. Ecophysiology of Sorghum Production. 1.ed. Sete Lagoas: EMBRAPA Maize and Sorghum, 2003. 4p. (Technical Communication, 87). Avaliable in: $<$ https://www.infoteca.cnptia.embrapa.br/ infoteca/bitstream/doc/487528/1/Com87. pdf>.

\section{MARTINS, L.S. Adaptability and stability of sorghum hybrids in the southwest of Goiás. 2015. 46f. \\ Dissertation (Master in Agronomy) - Rio Verde University, Rio Verde, GO. \\ MOREIRA, J.N.; LIRA, M.A.; SANTOS, M.V.F.; ARAÚJO, G.G.L.; SILVA, G.C. Potential for buffel grass production in the dry season in the semi- arid Pernambucano. Revista Caatinga [online], v.20, n.3, p.22-29, 2007.}


NEVES, A.L.A.; SANTOS, R.D.; PEREIRA, L.G.R.; TABOSA, J.N.; ALMEIDA, M.R.M.; RODRIGUES, J.A.S.; NEVES, A.L.A.; VERNEQUE, R.S. Agronomic characteristics of sorghum cultivars for silage production in the Agreste of Pernambuco state. Revista Brasileira de Milho e Sorgo [online], v.13, n.3, p.382-390, 2015.

OLIVEIRA, O.F.; SANTOS, M.V.F.; CUNHA, M.V.; MELLO, A.C.L.; LIRA, M.A.; BARROS, G.F.N.P. Características quantitativas e qualitativas de Caatinga raleada sob pastejo de ovinos, Serra Talhada (PE). Revista Caatinga [online], v.28, n.3, p.223-229, 2015.

PATERSON, A.H. Genomics of Sorghum. International Journal of Plant Genomics [online], v.2008, p.1-6, 2008.

PERAZZO, A.F.; CARVALHO, G.G.P.; SANTOS, E.M.; PINHO, R.M.A.; CAMPOS, F.S.; MACEDO, C.H.O.; AZEVÊDO. C.A.G.; TABOSA, J.N. Agronomic evaluation of 32 sorghum cultivars in the Brazilian semi-arid region.

Revista Brasileira de Zootecnia [online], v.43, n.5, p.232-237, 2014.

PERAZZO, A.F.; SANTOS, E.M.; PINHO, R.M.A.; CAMPOS, F.S.; RAMOS, J.P.F.; AQUINO, M.M.; SILVA, T.C.; BEZERRA, H.F.C.

Agronomic characteristics and efficiency of rainwater use in sorghum cultivars in the semiarid region. Ciência Rural [online], v.43, n.10, p.1771-1776, 2013.

SAEG. System for statistical analysis. Version 9.1. Viçosa: Arthur Bernardes Foundation, UFV, 2007.
SALEM, H.B. Nutritional management to improve sheep and goat performances in semiarid regions. Revista Brasileira de Zootecnia [online], v.39, p.337-347, 2010.

SANTOS, J.F.; GRANGEIRO, J.I.T. Productive performance of forage and grain sorghum cultivars in Paraíba. Tecnologia e Ciência Agropecuária [online], v.7, n.2, p.49-55, 2013.

SHER, A.; HASSAN, F.U.; ALI, H.; HUSSAIN, M.; SATTAR, A. Enhancing forage quality through appropriate nitrogen dose, seed rate and harvest stage, in sorghum cultivars grown in Pakistan. Grassland Science [online], v.63, p.1522, 2016.

SILVA, T.C.; SANTOS, E.M.; AZEVEDO, J.A.G.; EDVAN, R.L.; PERAZZO, A.F.; PINHO, R.M.A.; RODRIGUES, J.A.S; SILVA, D.S. Agronomic divergence of sorghum hybrids for silage yield in the semiarid region of Paraiba. Revista Brasileira de Zootecnia [online], v.40, n.9, p.18861893, 2011.

VAN BUREN, R.; BRYANT, D.; EDGER, P.P.; TANG, H.; BURGESS, D.; CHALLABATHULA, D.; SPITTLE, K.; HALL, R.; GU, J.; LYONS, E.; FREELING, M.; BARTELS, D.; HALLERS, T.; HASTIE, A.; MICHAEL, T.P.; MOCKLER, T.C. Single-molecule sequencing of the desiccation-tolerant grass Oropetium thomaeum. Nature [online], v.527, p.508-511, 2015.

Receipt date: 02/04/2018 Approval date: 11/07/2018 